\title{
The Correlation Between Expectation with Motivation of Adolescents to Improve Knowledge About Promiscuity and Sexual Health
}

\author{
Fransiska Ambarukmi Pontjosudargo* \\ Department of Anatomy, Faculty of Medicine \\ University of Jenderal Achmad Yani \\ Cimahi, Indonesia \\ *fransiska.ambarukmi@lecture.unjani.ac.id
}

\begin{abstract}
Adolescence is a transition period from childhood to adulthood, during which time individuals undergo changes both physically and psychologically, including the development and maturation of organs and functions of the reproductive system. Knowledge of reproductive health is important for adolescents, in order to know the proper and healthy function of reproductive organs responsibly. Adolescents who have a correct and proportionate understanding of reproductive health tend to understand the risks of free sex as well as alternatives that can be used to channel their sexual desires. This study aims to assess the correlation of adolescent percentions and their attitude after getting educated about adolescent promiscuity and sexual health. A total of 143 new students from Jenderal Achmad Yani University who participated in the webinar filled out a questionnaire that assessed the perception of their expectations with the motivation to deepen knowledge about the materials given. There are 9 educational themes given to improve adolescent knowledge about adolescent promiscuity and reproductive health. The data obtained was analyzed with Spearman's correlation test, with a $95 \%$ degree of confidence. Spearman's test results showed the meaningful relationship between the perception of expectations and the motivation of participants to improve knowledge. The $R$ value of 8 educational themes is more than 0.75 , indicating a strong positive relationship and 1 theme indicates an $R=0.445$ value indicating a moderate positive relationship. The conclusion of this study, the more appropriate adolescent expectations about adolescent social education and reproductive health, the higher the motivation to improve their knowledge.
\end{abstract}

Keywords-adolescent promiscuity, sexual health, education, students

\section{INTRODUCTION}

Adolescence is a period of transition from child to adulthood. At this time, individuals experience changes both physically and psychologically. Changes that occur during adolescence include the emergence of a process of development and maturation of reproductive organs and functions. Indonesian adolescents cover $37 \%$ of the population, but very little information related to reproductive health is aimed at them and they have. Society still considers taboo on everything related to sex, including talking, providing information, and sex education. Therefore, adolescents look for various sources of information that might be obtained, for example discussing it with their peers, incomplete explanations from parents, reading books about sex, or experimenting with masturbation, flirting, or copulating $[1,2]$.

Based on BKKBN data, the results of the last survey in 33 provinces in Indonesia in 2008 showed an increase in the number of adolescents who admitted to having sex outside of marriage by $63 \%$. There were $2.88 \%$ male subjects and $11.5 \%$ female subjects having sex at the age of 12-14 years. Most of the reasons for male subjects having sex as evidence of love were $47.73 \%$, while $44 \%$ of female subjects had sex for the first time based on the desire to try. Another problem related to sexual behavior is a change in sexual orientation $[2,3]$.

Normally sexual orientation is romantic attraction, sexual attraction, or having sexual relations with the opposite sex. Heterosexual refers to a fixed pattern or disposition for experiencing sexual, affectionate, physical, or romantic attraction towards the opposite sex. Normal sexual orientation is people who are emotionally and sexually attracted to the opposite sex (PKBI). Sexual deviations consist of transsexual, zoophilia, pedophilia, sexual sadism, and homosexuality. Homosexuality is physical romantic attraction to someone of the sex that occurs in men with men or women with women. Homosexuals are attracted physically, sexually, emotionally, and romantically to the same sex. The United Nations (UN) Agency revealed that in 2009 the number of homosexuals, including bisexual, and transgender people in Indonesia was recorded at 800 thousand, and in 2011 it is predicted to increase to three million people [4,5].

The impact of promiscuity on adolescents related to sexual behavior is the risk of being infected with various sexually transmitted diseases. The Center for Data and Information of the Ministry of Health of the Republic of Indonesia reported that until the first quarter of 2016 the cumulative number of 
HIV-positive sufferers in Indonesia was 191,073 people and AIDS was 77,940 people. Even if a predictive analysis is carried out based on the existing risk factors, the number, and size of HIV / AIDS problems in the field are far greater than the reported cases. In 2017 there were 36.9 million people newly infected with HIV or around 5000 new infections every day. Asia Pacific is a region with the second-largest number of HIV cases in the world. Indonesia ranks third in the number of people living with HIV in the Southeast Asia region after India and China. AIDS mortality in Indonesia increased by $68 \%$ in 2016. Data from the Ministry of Health noted that in the first quarter the number of reported HIV infections was 10,376 people, where the ratio of HIV between women and men was 2 to $1[5-7]$.

To prevent the sexual deviant behavior, one of the approaches needed is to provide education to adolescents. Knowledge of reproductive health is especially important for adolescents so that adolescents know reproductive functions correctly and are healthy and responsible). Adolescents who have a correct and proportionate understanding of reproductive health tend to understand the risks of free sex and alternative ways that can be used to channel their sexual urges $[2,3]$. Thraneou in his study observes the motivation of students to increase their knowledge according to their expectations. The results showed that the respondents' participation was greater if it was expected that the skills and knowledge gained from the training were considered very important to them [8]. Someone are intrinsically motivated when an activity leads to satisfaction or fulfils a personal interest. Intrinsic motivation has been found to have a positive impact on student performance [9]. This study aims to assess the correlation of adolescent expectation and motivation after getting educated about adolescent promiscuity and sexual health.

\section{METHODS}

Socialization and education of adolescent promiscuity and sexual health were conducted to new students of the Jenderal Achmad Yani University. This activity involves lecturers, students, and young doctors. New students were educated with nine topics on adolescent promiscuity and reproductive health. The socialization program is implemented in 2 days. On the first day, themes 1 to 5 were presented. On the second day, themes 6 to 9 were presented.

After the training and simulations were conducted, 143 new students of Jenderal Achmad Yani University (Unjani) were given questionnaires to assess their perception about the expectation and motivation to improve their knowledge about the themes. The survey instrument used was taken from a questionnaire designed by Cohen and Kinsey but adapted from Aldoory and Wringley. Eight items were adapted from the tool to measure the key variables in this study: (1) level of motivation to engage in learning, and (2) expectations of participation in the project. A Likert scale was used in all questions, with responses ranging from strongly disagree (1) to strongly agree (5). Previous studies have confirmed increased validity and flexibility [10]. The data obtained were processed using the Spearman test with a degree of trust of $95 \%$.

\section{RESULTS AND DISCUSSION}

The implementation of adolescent promiscuity and reproductive health education was conducted in two sessions. Both sessions conducted online. On the first day of the activity, the participants were presented with theme 1 to 5 , and on the second day, theme 6 to 9 were presented. After the presentation session, 143 participants answered the questionnaire. The results shown in Table 1.

TABLE I. DESCRIPTIONS OF PARTICIPANTS' EXPECTATIONS AND Motivations BASED ON THE THEMES ON THE FIRST DAY

\begin{tabular}{|c|c|c|c|c|}
\hline \multirow{2}{*}{ Variable } & \multicolumn{2}{|c|}{ Expectation } & \multicolumn{2}{|c|}{ Motivation } \\
\hline & $N$ & $\%$ & $N$ & $\%$ \\
\hline \multicolumn{5}{|c|}{ Theme 1} \\
\hline Strongly Disagree & 3 & 2.1 & 3 & 2.1 \\
\hline Disagree & 0 & 0 & 0 & 0 \\
\hline Undecided & 3 & 2.1 & 8 & 5.6 \\
\hline Agree & 66 & 46.2 & 57 & 39.9 \\
\hline Strongly Agree & 71 & 49.7 & 75 & 52.4 \\
\hline Total & 143 & 100 & 143 & 100 \\
\hline \multicolumn{5}{|c|}{ Theme 2} \\
\hline Strongly Disagree & 3 & 2.1 & 3 & 2.1 \\
\hline Disagree & 0 & 0 & 0 & 0 \\
\hline Undecided & 2 & 1.4 & 3 & 2.1 \\
\hline Agree & 67 & 46.9 & 51 & 35.7 \\
\hline Strongly Agree & 71 & 49.7 & 86 & 60.1 \\
\hline Total & 143 & 100 & 143 & 100 \\
\hline \multicolumn{5}{|c|}{ Theme 3} \\
\hline Strongly Disagree & 3 & 2.1 & 3 & 2.1 \\
\hline Disagree & 0 & 0 & 0 & 0 \\
\hline Undecided & 6 & 4.2 & 6 & 4.2 \\
\hline Agree & 60 & 42.0 & 51 & 35.7 \\
\hline Strongly Agree & 74 & 51.7 & 83 & 58 \\
\hline Total & 143 & 100 & 143 & 100 \\
\hline \multicolumn{5}{|c|}{ Theme 4} \\
\hline Strongly Disagree & 3 & 2.1 & 3 & 2.1 \\
\hline Disagree & 0 & 0 & 0 & 0 \\
\hline Undecided & 9 & 6.3 & 3 & 2.1 \\
\hline Agree & 55 & 38.5 & 54 & 37.8 \\
\hline Strongly Agree & 76 & 53.1 & 83 & 58 \\
\hline Total & 143 & 100 & 143 & 100 \\
\hline \multicolumn{5}{|c|}{ Theme 5} \\
\hline Strongly Disagree & 3 & 2.1 & 3 & 2.1 \\
\hline Disagree & 0 & 0 & 0 & 0 \\
\hline Undecided & 3 & 2.1 & 3 & 2.1 \\
\hline Agree & 52 & 36.4 & 46 & 32.2 \\
\hline Strongly Agree & 85 & 59.4 & 91 & 63.6 \\
\hline Total & 143 & 100 & 143 & 100 \\
\hline
\end{tabular}


TABLE II. DESCRIPTIONS OF PARTICIPANTS' EXPECTATIONS AND MOTIVATIONS BASED ON THE THEMES ON THE SECOND DAY

\begin{tabular}{|c|c|c|c|c|}
\hline \multirow{2}{*}{ Variable } & \multicolumn{2}{|c|}{ Expectation } & \multicolumn{2}{|c|}{ Motivation } \\
\hline & $N$ & $\%$ & $N$ & $\%$ \\
\hline \multicolumn{5}{|c|}{ Theme 6} \\
\hline Strongly Disagree & 3 & 2.1 & 3 & 2.1 \\
\hline Disagree & 0 & 0 & 0 & 0 \\
\hline Undecided & 3 & 2.1 & 9 & 6.3 \\
\hline Agree & 65 & 45.5 & 54 & 37.8 \\
\hline Strongly Agree & 72 & 50.3 & 77 & 53.8 \\
\hline Total & 143 & 100 & 143 & 100 \\
\hline \multicolumn{5}{|c|}{ Theme 7} \\
\hline Strongly Disagree & 3 & 2.1 & 3 & 2.1 \\
\hline Disagree & 0 & 0 & 0 & 0 \\
\hline Undecided & 3 & 2.1 & 8 & 5.6 \\
\hline Agree & 65 & 45.5 & 57 & 39.9 \\
\hline Strongly Agree & 72 & 50.3 & 75 & 52.4 \\
\hline Total & 143 & 100 & 143 & 100 \\
\hline \multicolumn{5}{|c|}{ Theme 8} \\
\hline Strongly Disagree & 4 & 2.8 & 4 & 2.8 \\
\hline Disagree & 0 & 0 & 0 & 0 \\
\hline Undecided & 2 & 1.4 & 7 & 4.9 \\
\hline Agree & 63 & 44.1 & 55 & 38.5 \\
\hline Strongly Agree & 74 & 51.7 & 77 & 53.8 \\
\hline Total & 143 & 100 & 143 & 100 \\
\hline \multicolumn{5}{|c|}{ Theme 6} \\
\hline Strongly Disagree & 3 & 2.1 & 3 & 2.1 \\
\hline Disagree & 0 & 0 & 0 & 0 \\
\hline Undecided & 3 & 2.1 & 9 & 6.3 \\
\hline Agree & 65 & 45.5 & 54 & 37.8 \\
\hline Strongly Agree & 72 & 50.3 & 77 & 53.8 \\
\hline Total & 143 & 100 & 143 & 100 \\
\hline
\end{tabular}

Table 1 and Table 2 showed that of the nine themes presented, there were $3-4$ participants $(2.1 \%$ - $2.8 \%)$ who stated that they strongly disagreed with this education in accordance with their expectations and wanted to increase their knowledge of the topics presented. However, most of the participants, 52 $67(36.4 \%$ - 46.9\%) agreed, and $70-85(49 \%-59.5 \%)$ strongly agreed that education about adolescent relationships and reproductive health met their expectations and want to increase his knowledge about the material. The relationship between perceptions of expectations and motivation of participants to increase knowledge about each of the given themes was tested with the Spearman test, the results of which can be seen in Table 3 .

Spearman's test results showed a value of $\mathrm{p}=0.000(\mathrm{p}$ $<0.05$ ) for all educational themes, which means there is a meaningful relationship between the perception of expectations and the motivation of participants to improve knowledge. The $\mathrm{R}$-value of 8 educational themes is more than 0.75 , indicating a strong positive relationship and 1 theme shows the value of $\mathrm{R}=$ 0.445 , which indicates a moderate positive relationship. It means the higher the perception of the expectation, the higher the motivation of participants in improving their knowledge about adolescent promiscuity and reproductive health. The results of this study are in line with study conducted by Dani, 2015 which states that there is a relationship between expectations and a person's motivation to take any action/decision. Muturi et al in their study showed that prior participation did not affect attitudes or expectations, however motivation to participate was significantly associated with positive attitudes higher expectations [10].

TABLE III. THE CORRELATION BETWEEN EXPECTATION AND MOTIVATION BY SPEARMEN TEST

\begin{tabular}{|c|c|c|c|}
\hline Variable & $\mathbf{n}$ & $\mathbf{R}$ & p-value \\
\hline \multicolumn{4}{|c|}{ Theme 1} \\
\hline Expectation & 143 & 0,804 & \multirow[t]{2}{*}{$0,000 *$} \\
\hline Motivation & 143 & & \\
\hline \multicolumn{4}{|l|}{ Theme 2} \\
\hline Expectation & 143 & 0,815 & \multirow[t]{2}{*}{$0,000 *$} \\
\hline Motivation & 143 & & \\
\hline \multicolumn{4}{|c|}{ Theme 3} \\
\hline Expectation & 143 & 0,815 & \multirow[t]{2}{*}{$0,000 *$} \\
\hline Motivation & 143 & & \\
\hline \multicolumn{4}{|c|}{ Theme 4} \\
\hline Expectation & 43 & 0,863 & $0,000 *$ \\
\hline Motivation & 143 & & \\
\hline \multicolumn{4}{|c|}{ Theme 5} \\
\hline Expectation & 143 & 0,924 & $0,000 *$ \\
\hline Motivation & 143 & & \\
\hline \multicolumn{4}{|c|}{ Theme 6} \\
\hline Expectation & 143 & 0,445 & \multirow[t]{2}{*}{$0,000^{*}$} \\
\hline Motivation & 143 & & \\
\hline \multicolumn{4}{|c|}{ Theme 7} \\
\hline Expectation & 143 & 0,792 & \multirow[t]{2}{*}{$0,000 *$} \\
\hline Motivation & 143 & & \\
\hline \multicolumn{4}{|c|}{ Theme 8} \\
\hline Expectation & 143 & 0.823 & \multirow[t]{2}{*}{$0,000^{*}$} \\
\hline Motivation & 143 & & \\
\hline \multicolumn{4}{|c|}{ Theme 9} \\
\hline Expectation & 143 & 0.820 & $0,000 *$ \\
\hline Motivation & 143 & & \\
\hline
\end{tabular}

Expectancy motivation theory (1964) provide evidence that student expectations is very important for their behavior orientation [11]. Expectation can be described as the first essence/estimation created by someone while receiving the action. The expectation is an effective element which means it is important to understand. Attitude is one of the elements to understand someone's motivation and behavior. Attitude can be described as positive or negative evaluations of an object, events, activities, or ideas. Individuals' attitudes towards something can be positive or negative depending on three components, which are cognitive, affective, and behavioral. A positive attitude creates a tendency to like, approach, accept, or even expect the presence of certain objects. Meanwhile, negative attitudes lead to a tendency to know, hate, avoid, or dislike the existence of an object. Motivation conceptualizes expectancy and valance. Motivation can also be influenced by deceiving the individual's expectation cues and the incentive value of the consequences that lead to his / her action. Motivation and the learning process have a deep relationship. Motivation is at the heart of human aspirations. So, motivation is essential to succeed in educational matters and in real life. 
Motivation is a force that encourages students to face all difficulties and challenging circumstances [1,12-15].

Motivation is the driving force to do something. Achievement motivation is one of the factors affecting students' success. Achievement motivation will put students in a condition of willing to do something. This is the heart of the teaching and learning process. Higher motivation will lead to perseverance in learning. Yet, low-motivated students will feel constrained in studying, leading to less maximal achievement. Besides motivation, students' expectations and desire on how teachers act in the class are also affecting the smoothness of the teaching and learning process. If the teacher could meet the expectations, then students will learn calmly, passionately, and full of motivation. Contrary, if they do not meet their expectations, a student will be disappointed and frustrated [14]. This is shown from the results of this study, it appears that the participants who stated that they strongly disagreed with the hope of the importance of the educational material provided, also stated that they strongly disagreed with having the motivation to increase the knowledge they had.

The social environment is one of the factors that can influence a person or group to be able to take an action and change the behavior of each individual [16]. The social environment can influence the values adopted by a person/society to determine whether something is said to be good or bad, appropriate or inappropriate, and must go through a weighing process. Thus association is one of the environmental factors that can affect a person's values $[1,16]$. Education about adolescent relationships and reproductive health is an effort to increase adolescent knowledge so that it is expected to influence the values they adhere to. This is in accordance with the study of Sulistyaningsih [2], which assessed the relationship between the social environment and the level of knowledge of reproductive health with free sex attitudes. The better the social environment and the level of knowledge on reproductive health, the less free sex attitudes are to adolescents. Thus the higher the expectations of Unjani students on the importance of education about adolescent relationships and reproductive health, the more their motivation to deepen their knowledge and hopefully will further prevent them from the bad effects of adolescent promiscuity.

\section{CONCLUSION}

The correlation between the expectation and motivation of the new students of the University showed a positive correlation with the strength of the relationship very strongly, meaning the better the expectation of educational benefits, the higher motivation of participants to improve their knowledge of adolescent promiscuity and reproductive health.

\section{REFERENCES}

[1] B. Pitoewas, "Pengaruh Lingkungan Sosial Dan Sikap Remaja Terhadap Perubahan Tata Nilai," JPK, vol. 3, no. 1, pp. 8 - 18, 2018

[2] A. Sulistyaningsih, Hubungan Lingkungan Pergaulan Dan Tingka Pengetahuan Tentang Kesehatan Reproduksi Dengan Sikap Seks Bebas Pada Remaja. Surakarta: UNS-F.Kedoteran Prog. D.IV KebidananR.0106003-2010.

[3] I. Ratnasari and C. Rambi, "Gambaran Perilaku Seksual Pranikah Pada Mahasiswa Keperawatan Jurusan Kesehatan Politeknik Negeri Nusa Utara,” Jurnal Ilmiah Sèsebanua, vol. 1, no. 2, pp. 73-77, 2017.

[4] A. Rivai, "Gambaran Faktor-Faktor Penyebab Seseorang Menjadi Homoseksual Pada Laki-Laki," Journal of Nursing Science, vol 7, no. 2 , pp. 31-40, 2018

[5] N.K. Azhari, H. Susanti, and I.Y. Susanti, "Persepsi Gay Terhadap Penyebab Homoseksual," Jurnal Keperawatan Jiwa, vol 7, no. 1, pp. 1-6, 2019.

[6] D. Hawari, Pendekatan Psikoreligi Pada Homoseksual. Jakarta: Balai Penerbit FKUI, 2009.

[7] H. Hardisman, F. Firdawati, and I.N. Sulrieni, "Model Determinan Perilaku "Lelaki Seks Lelaki" Di Kota Padang, Sumatera Barat," Jurnal Kesehatan Andalas, vol. 7, pp. 302-313, 2018.

[8] P. Tharenou, "The Relationship Of Training Motivation To Participation In Training And Development," Academy of Management Annual Meeting Proceedings (1):E1-E6, 2001

[9] L. Hornstra, K. Stroet, E.V. Eijden, J. Goudsblom, and C. Roskamp, "Teacher Expectation Effects On Need-Supportive Teaching, Student Motivation, And Engagement: A Self-Determination Perspective," Educational Research and Evaluation, DOI: 10.1080/13803611.2018.1550841, 2018.

[10] N. Muturi, S. An, and S. Mwangi, "Students' expectations and motivation for service-learning in public relations," Journalism \& Mass Communication Educator, vol. 68, pp. 387-408, 2013.

[11] S. Zukan and S.H. Aldulaimi, "The Influence Of Grade Expectation And Student Motivation For Academic Performance," International Journal Of Scientific \& Technology Research, vol. 9, 2020.

[12] R. Dani, G.T. Utami, and Bayhakki, "Hubungan Motivasi, Harapan, Dan Dukungan Petugas Kesehatan Terhadap Kepatuhan Pasien Gagal Ginjal Kronik Untuk Menjalani Hemodialisis,” JOM, vol 2, no 2, pp. $1362-$ 1371, 2018.

[13] D.G. Anugrah and Noermijati, "The Role Of Motivation In Mediating Effect Of Expectation To Attitude," Journal of Applied Management (JAM), vol. 16, no. 3, pp. 412-421, 2017

[14] V. Gopalan, J.A.A. Bakar, A.N. Zulkifli, A. Alwi, and R.C. Mat, "A review of the motivation theories in learning", AIP Conference Proceedings 1891, 020043, 2017.

[15] N. Hidayati, "The Effect Of Achievement Motivation And Expectation Toward Students' Learning Achievement On Islamic Education," Jurnal Kajian Pendidikan Islam, vol. 9, no. 2, 208 -227, 2017.

[16] M.M. Sapara, J. Lumintang, and C.J. Paat, "Dampak Lingkungan Sosial Terhadap Perubahan Perilaku Remaja Perempuan Di Desa Ammat Kecamatan Tampan'amma Kabupaten Kepulauan Talaud,' Jurnal Holistik, vol. 13, no. 3, pp. $1-16,2020$. 